\title{
Effects of seston concentration on feeding, digestion and growth in the mussel Mytilus edulis
}

\author{
B. L. Bayne ${ }^{1}$, A. J. S. Hawkins ${ }^{1}$, E. Navarro ${ }^{2}$, I. P. Iglesias ${ }^{2}$ \\ ${ }^{1}$ Plymouth Marine Laboratory, West Hoe, Plymouth PL1 3DH, England \\ ${ }^{2}$ Departmento de Biologia, Universidad del Pais Vasco, Aptdo 644-48080, Bilbao, Spain
}

\begin{abstract}
Mussels Mytilus edulis L. were fed a mixed diet comprising 2 algal species and ashed silt at a range of concentrations simulating natural conditions both above and below the level at which pseudofaeces were produced. Rates of ingestion increased to an asymptotic value at the highest concentration tested. Although gut passage times declined with increasing ingestion rate, efficiencies of food absorption remained relatively constant, probably signifying a balance between total gut contents and the rate of production of digestive enzymes. Measured physiological rates were similar to those recorded for mussels in the natural habitat. Respiration rates increased exponentially with increased rates of absorption, and the scope for growth was linearly related to absorbed ration, reaching a maximum value at the highest ration concentrations tested. The metabolic costs of feeding and growth represented $16 \%$ of the absorbed ration at twice the maintenance requirement, and increased to $22 \%$ at $4 \times$ maintenance. Despite these increased respiratory losses, we conclude that the limits to growth are set primarily by constraints on feeding behaviour, particularly on the processes of digestion and absorption.
\end{abstract}

\section{INTRODUCTION}

Mussels Mytilus edulis live in estuarine and coastal environments where the concentration of suspended particulate matter (seston) is often high and variable (Bayne \& Widdows 1978, Incze et al. 1980, Rodhouse et al. 1984, Smaal et al. 1986). For example, in the Lynher estuary in southwest England, seston concentrations in the water immediately above the banks of mussels on the intertidal mud flats vary between $<3$ and $>100 \mathrm{mg}$ $\mathrm{l}^{-1}$ (Widdows et al. 1979, Bayne et al. 1987). Between 5 and $30 \%$ of this seston may be organic in nature, with chlorophyll a concentrations between 0 and $5 \mu \mathrm{g} \mathrm{l}^{-1}$, depending on tide and season (Widdows et al. 1979). Bayne et al. (1978) measured particulate organic matter (POM) at this site between 1.2 and $4.8 \mathrm{mg} \mathrm{l}^{-1}$ over an annual cycle.

There have been many studies of how such variability in suspended particulates may affect the feeding behaviour of mussels (Winter 1973, Foster-Smith 1975, Schulte 1975, Kiørboe et al. 1981, Navarro \& Winter 1982; see reviews by Winter 1978 and Bayne \& Newell 1983). However, most of these experiments have varied the concentration of a single algal species in suspension. Where comparisons have been made between the effects of such single-species suspensions and seston more representative of the natural condition (Griffiths 1980), then significant differences in feeding behaviour have been observed. Clearly, given the range of food quality and quantity experienced in the natural habitat, experiments with diets simulating natural seston are essential if they are to be relevant, for example, to an understanding of the impact of suspension feeders on particle fluxes in coastal environments (Tenore \& Dunstan 1973, Buss \& Jackson 1981, Cloern 1982, Officer et al. 1982, Doering \& Oviatt 1986, Kautsky \& Evans 1987)

In designing experimental diets which are representative of natural seston, attention is due to relationships between particle volume and organic content. For example, Widdows et al. (1979) recorded large seasonal variability in median particle volumes; in winter, the seston was dominated by small particles $(<6 \mu \mathrm{m}$ equivalent spherical diameter) with a low $(<20 \%)$ organic content, whereas in spring the dominant particles were larger (> $15 \mu \mathrm{m}$ ) with a higher organic con- 
tent $(<40 \%)$. The organic content per unit particle volume (Bayne et al. 1987, Wilson 1987) is important in defining dietary quality for suspension feeders, probably because of the volumetric constraints that are inherent in digestion (Taghon 1981, Taghon \& Jumars 1984).

Recently Bayne et al. (1987) reported experiments on the feeding behaviour of mussels offered diets of different food quality, with 'quality' defined as the mass of organic material present in suspension per unit volume of particulate matter. Measurements were made at low seston concentrations and demonstrated the ability of Mytilus edulis to acclimate aspects of its feeding behaviour to result in physiological compensation (measured as net energy available for growth) for variable dietary quality over the range 0.25 to $0.43 \mathrm{mg}$ POM per $\mathrm{mm}^{3}$ particle volume.

The aim of the experiments reported here was to determine how feeding, digestion and the scope for growth are affected in mussels held at different seston concentrations, with the diets made up to cover a range of concentrations of organic matter, but with dietary quality (as defined above) taking values previously shown to be within the capacity of these mussels for physiological compensation. Seston concentrations were chosen to cover a range $\left(<1\right.$ to $\left.>7 \mathrm{mg} \mathrm{l}^{-1}\right)$ that included, at the upper end, levels known to induce the production of pseudofaeces, which is comprised of material cleared from suspension but rejected by the mussel before ingestion (Foster-Smith 1975, Widdows et al. 1979). In these circumstances, the hypothesis of Winter (1978), as elaborated by Widdows et al. (1979), that rates of ingestion will increase with increased particle concentration, to an asymptotic value which is coincident with the threshold for pseudofaeces production, may be tested. In addition, we aimed to measure some of the other physiological traits (such as gut passage times, absorption efficiencies and the rates of oxygen consumption) that determine the rates of growth of the mussels in these conditions; to explore relationships between these aspects of feeding behaviour; and to examine the hypothesis that metabolic costs associated with feeding and growth set limits upon the rate of growth that can be achieved.

\section{MATERIAL AND METHODS}

Mytilus edulis L. of $2.5 \pm 0.3 \mathrm{~cm}$ were collected from the Lynher estuary near Plymouth on 23 June 1986. On return to the laboratory the mussels were cleaned of epibionts and placed in trays of running seawater at $14 \pm 1{ }^{\circ} \mathrm{C}, 32 \pm 2 \%$ salinity and water flows of $200 \mathrm{ml}$ $\mathrm{min}^{-1}$. The mussels were divided into 6 groups and held for $19 \mathrm{~d}$ on different diets as described below. Physiological determinations were made according to the following timetable: ingestion rates and absorption efficiencies were measured 15 and 16 d after collection; rates of passage of ingested material through the gut (gut passage times) were determined on Day 17; rates of oxygen consumption were measured on Days 18 and 19 for mussels from the feeding trays, and repeated 2 and 5 d later for mussels removed to trays of filtered seawater, in order to discriminate between 'routine' and 'standard' respiration rates as defined by Thompson \& Bayne (1972). All mussels were then sacrificed and dry tissue weights determined after drying overnight at $80^{\circ} \mathrm{C}$.

Experimental diets were made up by mixing cells of the algae Isochrysis galbana Parke and Phaeodactylum tricornutum Bohlin, grown in uni-algal (though not bacteria-free) culture, with silt which was collected from surficial sediments in the Lyhner estuary. This silt had previously been dried, ashed at $450^{\circ} \mathrm{C}$, ground and then sieved to produce particles in suspension with a median diameter of ca $4 \mu \mathrm{m}$, as determined with a Coulter Counter TAII. The 6 diets are described in Table 1, where the variance for each measurement covers 3 determinations made on each of $2 \mathrm{~d}$ for each feeding tray. Each diet was made up fresh daily, after monitoring the algal cultures for cell concentrations and volumes, according to a protocol designed to yield low (ca $20 \%$ ) and high (ca $70 \%$ ) values for POM as a percent of the following 3 seston concentrations; low

Table 1. Experimental diets. Diets were mixed from actively growing Isochrysis galbana and Phaeodactylum tricomutum cultures ( $2: 3$ by volume) and ashed silt. POM: particulate organic matter

\begin{tabular}{|c|c|c|c|c|c|}
\hline \multirow[t]{2}{*}{ Diet } & \multicolumn{2}{|c|}{ Seston } & \multicolumn{2}{|c|}{ POM } & \multirow{2}{*}{$\begin{array}{c}\text { Diet quality } \\
\text { (mg POM } \mathrm{mm}^{-3} \text { seston) }\end{array}$} \\
\hline & $\left(\mathrm{mg} \mathrm{l}^{-1}\right)$ & $\left(\mathrm{mm}^{3} \mathrm{l}^{-1}\right)$ & $\left(\mathrm{mg} \mathrm{l}^{-1}\right)$ & ( $\%$ of seston) & \\
\hline 1 & $0.79 \pm 0.10$ & $1.08 \pm 0.16$ & $0.49 \pm 0.07$ & $62.1 \pm 8.5$ & $0.45 \pm 0.05$ \\
\hline 2 & $1.98 \pm 0.22$ & $1.06 \pm 0.14$ & $0.43 \pm 0.06$ & $21.9 \pm 2.2$ & $0.41 \pm 0.05$ \\
\hline 3 & $1.25 \pm 0.16$ & $2.50 \pm 0.48$ & $0.86 \pm 0.08$ & $70.0 \pm 4.4$ & $0.35 \pm 0.04$ \\
\hline 4 & $3.17 \pm 0.37$ & $2.22 \pm 0.42$ & $0.60 \pm 0.08$ & $18.8 \pm 2.0$ & $0.28 \pm 0.06$ \\
\hline 5 & $2.49 \pm 0.34$ & $4.90 \pm 0.34$ & $1.79 \pm 0.22$ & $71.0 \pm 8.9$ & $0.37 \pm 0.06$ \\
\hline 6 & $7.43 \pm 1.27$ & $5.14 \pm 0.76$ & $1.30 \pm 0.23$ & $17.7 \pm 2.2$ & $0.28 \pm 0.08$ \\
\hline
\end{tabular}


(ca $1.0 \mathrm{mg} \mathrm{l}^{-1}$ ), medium (ca $2.5 \mathrm{mg} \mathrm{l}^{-1}$ ) and high (ca $5.0 \mathrm{mg} \mathrm{l}^{-1}$ ). Care was taken to hold the food quality of each diet within the range 0.25 to $0.45 \mathrm{mg}$ POM per $\mathrm{mm}^{3}$ of particulate matter. The outcome was experimental concentrations of seston and POM (the latter from 0.4 to $1.8 \mathrm{mg} \mathrm{l}^{-1}$ ) which spanned the lower end of the range for natural seston in the Lynher, and included one concentration (Diet 6) at which significant pseudofaeces were produced. The energy equivalent of the diet was estimated to be $20.3 \mathrm{~J} \mathrm{mg} \mathrm{POM}^{-1}$.

Ingestion rates were determined by sampling the water entering and leaving the feeding trays, filtering the suspended particulate material onto pre-ashed Whatman GF/C glassfibre filters, washing with ammonium formate which was isotonic with seawater, drying $\left(100^{\circ} \mathrm{C}\right.$ overnight), weighing, and then ashing $\left(450^{\circ} \mathrm{C}\right.$ for $\left.6 \mathrm{~h}\right)$ before final weighing. Checks were made confirming that there was no settlement of seston in the feeding trays. Water flow rates through the trays were held constant at $12 \mathrm{I} \mathrm{h}^{-1}$; ingestion rates were calculated as the difference between inflow and outflow seston (or POM) concentrations, multiplied by the flow rate and divided by the numbers of mussels (12) in each tray. At the highest seston concentration (Diet 6), true faeces and pseudofaeces were collected separately from the feeding trays, dried and weighed, and the true ingestion rate then determined by weighting the calculation of material cleared from suspension by $(1-p)$, where $p$ is the proportion of material cleared which was rejected as pseudofaeces. Results are quoted for 6 independent determinations, as means $\pm 2 \mathrm{SE}$.

Absorption efficiencies (AE), gut passage times (GPT) and rates of oxygen consumption were determined as described by Bayne et al. (1987). AEs were estimated using the ash weight:organic weight ratio method of Conover (1966) and based on pooled faecal samples from each tray (12 mussels per tray) on each of 6 sampling occasions (results quoted as means $\pm 2 \mathrm{SE}$, for $n=6$ ). GPTs were determined by monitoring the appearance of ${ }^{14} \mathrm{C}$ in the faeces following a meal of ${ }^{14} \mathrm{C}$ labelled algae, experiments were carried out on 3 pools of 2 individuals for each diet and results are quoted as means $\pm 95 \% \mathrm{CI}$. These estimates were based on an interpolation in a regression analysis of cumulative egestion (following reciprocal square root transformation) of the ${ }^{14} \mathrm{C}$ label over time; regressions for each diet were statistically highly significant, explaining $>95 \%$ of total variability in ${ }^{14} \mathrm{C}$ recovery. The interpolated time at which $95 \%$ of all ${ }^{14} \mathrm{C}$ had been egested was used to register the GPT.

Rates of oxygen consumption were measured on 10 individuals taken from each feeding condition. The measurements were then repeated on 5 individuals after $2 \mathrm{~d}$ of starvation (achieved by holding the mussels in seawater filtered to $2 \mu \mathrm{m}$ ), and another 5 after $5 \mathrm{~d}$ starvation. These results are quoted as means $\pm 2 \mathrm{SE}$.

Tissue dry weights for mussels from each diet were as follows (means $\pm 2 \mathrm{SE}$ for $n=10$ determinations): Diet 1, $0.252 \pm 0.025 \mathrm{~g}$; Diet 2, $0.234 \pm 0.060 \mathrm{~g}$; Diet 3, $0.248 \pm 0.050 \mathrm{~g} ;$ Diet $4,0.249 \pm 0.027 \mathrm{~g} ;$ Diet 5, $0.277 \pm 0.044 \mathrm{~g}$; Diet $6,0.315 \pm 0.056 \mathrm{~g}$. Following provisional analysis of the results, all the physiological rates were then standardised to a tissue dry weight of $1.0 \mathrm{~g}$, as described by Bayne et al. (1987), for comparison of results with equivalent data from our earlier study (viz. mussels from the Lyhner, acclimated over 2 wk to 3 experimental diets; refer to Expt 5 in Bayne et al. 1987), in order to extend the range of food concentrations over which physiological responses had been determined; these 2 sets of experiments used equivalent procedures, on mussels from the same population and measured at the same time of year.

Statistical analysis of the data was based on a priori expectations of functional relationships between physiological traits and descriptors of the diet, and was effected by regression analysis. For example, we anticipated that the rate of ingestion of organic matter would be related to the availability of POM by a saturating function such as the Ivlev curve (see below). The expectations were then accepted or rejected on the basis of the normal criteria for goodness-of-fit. All statistical procedures were carried out using the StatGraphics package of Statistical Graphics Corp.

\section{RESULTS}

\section{Ingestion rates}

In order to estimate the true ingestion rate at the particle concentration at which pseudofaeces were produced, collections were made which discriminated between the dry mass of pseudofaeces and true faeces. On Diet 6, $22 \pm 5 \%$ of material cleared from suspension was rejected as pseudofaeces. However, as demonstrated by Kiørboe et al. (1980), Mytilus edulis is capable of sorting organic from inorganic material when producing pseudofaeces. We determined an efficiency of sorting of $50 \%$ at the Diet 6 seston concentration by comparing organic:inorganic ratios of the food and pseudofaeces. In other words, $12.8 \mathrm{mg}$ seston $\mathrm{h}^{-1}$, comprising $2.2 \mathrm{mg}$ POM, were cleared from suspension at Diet $6 ; 2.8 \mathrm{mg}$ seston $(=22 \%)$ were rejected as pseudofaeces, but this material comprised only $0.24 \mathrm{mg}$ POM. The total ingested ration as POM was therefore $[(12.8-2.8) \times 0.17]+0.24=1.94 \mathrm{mg} \mathrm{POM} \mathrm{h}^{-1}$.

The data relating rates of ingestion (IR) to the concentration of particles in suspension (Table 2) were fitted with an Ivlev curve of the form: 
Table 2. Mytilus edulis. Ingestion rates, gut passage times (GPT), absorption efficiency and estimated gut contents (see text) for mussels held for $2 \mathrm{wk}$ on 6 experimental diets. Ingestion rates are standardised to a dry flesh weight of $1 \mathrm{~g}$

\begin{tabular}{cccccrc}
\hline Diet & \multicolumn{2}{c}{$\begin{array}{c}\text { Ingestion rate } \\
\left(\mathrm{mgPOM} \mathrm{h}{ }^{-1}\right)\end{array}$} & $\begin{array}{c}\text { GPT } \\
(\mathrm{h})\end{array}$ & $\begin{array}{c}\text { Absorption } \\
\text { efficiency }\end{array}$ & $\begin{array}{c}\text { Gut content } \\
\left(\mathrm{mm}^{3}\right)\end{array}$ \\
\hline 1 & $1.90 \pm 0.47$ & $1.18 \pm 0.29$ & $2.67 \pm 0.08$ & $0.60 \pm 0.07$ & 6.9 \\
2 & $4.55 \pm 0.32$ & $0.99 \pm 0.02$ & $3.23 \pm 0.08$ & $0.63 \pm 0.10$ & 7.9 \\
3 & $2.27 \pm 0.71$ & $1.56 \pm 0.56$ & $2.73 \pm 0.13$ & $0.53 \pm 0.10$ & 12.4 \\
4 & $7.54 \pm 0.63$ & $1.43 \pm 0.12$ & $2.49 \pm 0.04$ & $0.55 \pm 0.04$ & 13.1 \\
5 & $2.64 \pm 0.87$ & $1.90 \pm 0.63$ & $1.87 \pm 0.17$ & $0.57 \pm 0.09$ & 9.7 \\
6 & $12.78 \pm 2.85$ & $1.97 \pm 0.50$ & $1.81 \pm 0.17$ & $0.50 \pm 0.08$ & 16.0 \\
\hline
\end{tabular}

$$
\operatorname{IR}=\operatorname{IR}_{\max }\left(1-\mathrm{e}^{-\mathrm{aC}}\right)
$$

where $\mathrm{IR}_{\max }=$ the predicted maximum rate of ingestion; $C=$ particle concentration; and $a=$ the rate at which maximum IR is approached. Regressions for the rate of ingestion of seston mass as a function of seston particle concentration $\left(F_{(2,7)}=68.2 ; p<0.001 ; r^{2}=\right.$ $82 \%)$, volumetric ingestion rate against total particulate volume $\left(F_{(2,7)}=81.5 ; p<0.001 ; r^{2}=82 \%\right)$ and rate of ingestion of organic mass related to the mass concentration of $\operatorname{POM}\left(F_{(2,7)}=1069 ; p<0.001 ; r^{2}=98 \%\right.$; Fig. 1) were all statistically significant.

The model fit to the data for the ingestion of organic material suggests that the observed IR at the highest food concentration in these experiments (viz. $2.24 \mathrm{mg}$ POM h ${ }^{-1} \mathrm{~g}^{-1}$ dry wt at $7.43 \mathrm{mg}$ seston $\mathrm{l}^{-1}$ ) is similar to the maximum predicted value $\left(2.1 \pm 0.1 \mathrm{mg} \mathrm{h}^{-1}\right.$; see legend to Fig. 1). This is consistent with our observation that pseudofaeces were produced by the mussels on this diet, and with the suggestion of Widdows et al. (1979) that the threshold for pseudofaeces production (i.e. the seston concentration above which pseudofaeces are produced) coincides with the maximum ingestion rate.

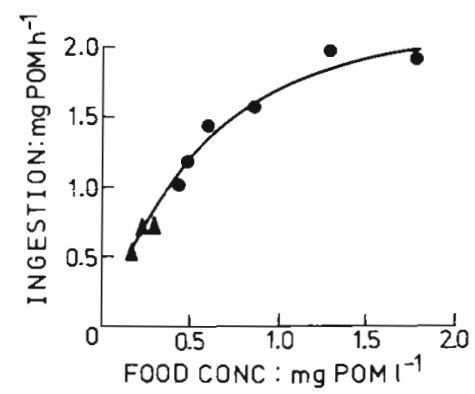

Fig. 1. Mytilus edulis. Feeding responses. Rate of ingestion of organic matter ( $I R$; $m g$ POM $h^{-1}$ ) related to the concentration of organic matter in suspension (POM; $\mathrm{mg} \mathrm{l}^{-1}$ ) by an Ivlev curve: $I R=2.1 \pm 0.1\left(1-\mathrm{e}^{(-1.64 \pm 0.16 \mathrm{POM})}\right) ; r^{2}=98 \%$. For these and subsequent graphs 3 data points from an earlier publication (Bayne et al. 1987; Expt 5 with Lynher mussels) are included (4) to represent values at the low end of the seston concentration range, with all physiological data standardised to a body size of $1 \mathrm{~g}$ dry flesh weight

\section{Gut passage time, absorption efficiency and gut content}

GPT (Table 2) declined with increase in the ingestion rate in a relationship modelled by an allometric function of the form GPT $=\mathrm{e}^{(a-b . I R)}\left(F_{(1,7)}=91 ; p<0.001 ; r^{2}\right.$ $=93 \%$; Fig. 2). AE (Table 2) showed no significant relationship with diet; a mean value across all 6 diets was $0.56 \pm 0.04$. The absorbed ration $(\mathrm{AR}=\mathrm{IR} \cdot \mathrm{AE})$ for these experiments and 3 appropriate values from the earlier study (Bayne et al. 1987; Lynher mussels, Expt 5) were significantly related $\left(F_{(2,7)}=739 ; p<0.001 ; r^{2}\right.$ $=93 \%$ ) to the concentration of particulate organic matter by the expression (see Eq. 1):

$$
A R=22.0 \pm 0.9\left(1-e^{-2.55 \pm 0.3} \mathrm{POM}\right)
$$

where $A R$ is in units of $\mathrm{J} \mathrm{h}^{-1}$. This suggests that $A R$ reached a maximum at a concentration of $1.9 \mathrm{mg} P O M$ $\mathrm{l}^{-1}$.

The maximal volume of material in the gut (gut content; $\mathrm{mm}^{3}$ ) may be estimated as $\mathrm{V}_{0} \cdot \mathrm{GPT}$ (Table 2), where $V_{0}$ is the volume of material ingested per $h_{\text {, and }}$ GPT is gut passage time in $h$. Gut content did not vary with changes in seston (or POM) concentration; the average value across 6 diets was $11.0 \pm 3.1 \mathrm{~mm}^{3}$. Our previous study (Bayne et al. 1987) suggested that gut content may be inversely related to dietary quality. By

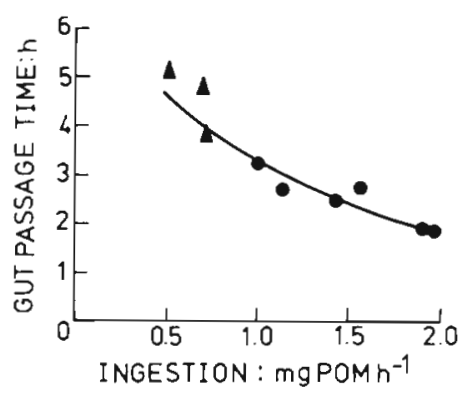

Fig. 2. Mytilus edulis. Feeding responses. Gut passage times (GPT; h) as a function of rates of ingestion of organic matter (IR: $\mathrm{mg}$ POM $\mathrm{h}^{-1}$ ). Data are fitted with an exponential model: GPT $=\mathrm{e}^{(1.92 \pm 09-0.68 \div 007 \mathrm{IR})} ; r^{2}=93 \%$ 
Table 3. Mytilus edulis. Rates of oxygen consumption (m. $\mathrm{O}_{2} \mathrm{~g}^{-1} \mathrm{~h}^{-1}$ ) by mussels feeding on 6 diets, and when starved for 2 and $5 \mathrm{~d}$. Values are means $\pm 2 \mathrm{SE}$ for $n=10$ (fed mussels) and for $n=5$ (starved mussels)

\begin{tabular}{|cccc|}
\hline Diet & Fed & Starved 2d & Starved 5d \\
\hline 1 & $0.337 \pm .068$ & $0.252 \pm .076$ & $0.249 \pm .091$ \\
2 & $0.325 \pm .082$ & $0.252 \pm .023$ & $0.238 \pm .011$ \\
3 & $0.436 \pm .156$ & $0.323 \pm .085$ & $0.272 \pm .073$ \\
4 & $0.405 \pm 119$ & $0.283 \pm .048$ & $0.238 \pm .025$ \\
5 & $0.433 \pm .099$ & $0.337 \pm .054$ & $0.246 \pm .079$ \\
6 & $0.456 \pm .102$ & $0.283 \pm .031$ & $0.249 \pm .042$ \\
\hline
\end{tabular}

pooling all available data, i.e. 9 combinations of food quality $\left(0.25\right.$ to $0.45 \mathrm{mg}$ POM mm $\left.\mathrm{mm}^{-3}\right)$ and quantity $(0.69$ to $5.14 \mathrm{~mm}^{3} \mathrm{l}^{-1}$ ), and analysing by ANOVA, quality emerges as exerting a significant effect on total gut content $\left(F_{(2,4)}=13.5 ; p<0.025>0.01\right)$ with no significant effect due to food quantity. However, when calculated for the organic component of the diet only, gut content did not vary with changes in either food quality or quantity.

\section{Respiration rates}

The rates of oxygen consumption by mussels in the feeding trays (Table 3 ) increased exponentially with increase in absorbed ration $\left(F_{(1,8)}=74.8 ; p<0.001 ; I^{2}\right.$ $=90 \%)$; in Fig. 3 the measured rates have been converted to their energy equivalents $(20.08 \mathrm{~J}[\mathrm{ml}$ oxygen $]^{-1}$; Gnaiger 1983). When the mussels were then transferred to filtered seawater, rates of oxygen consumption declined rapidly (Table 3 ) to converge, by $5 \mathrm{~d}$, at a standard rate of $0.249 \pm 0.011 \mathrm{ml} \mathrm{O}_{2} \mathrm{~g}^{-1} \mathrm{~h}^{-1}$ for all conditions, equivalent to $5.0 \pm 0.22 \mathrm{~J} \mathrm{~g}^{-1} \mathrm{~h}^{-1}$.

\section{Scope for growth and growth efficiency}

Rates of nitrogen excretion were not determined in these experiments. The calculated scope for growth ( $\mathrm{SFG}$ ) is therefore based on the difference between absorbed ration and respiratory loss (routine rate), and will be a slight (Bayne \& Newell 1983) over-estimate of the true scope for growth. The scope for growth increased with an increase in suspended POM $l^{-1}$, to reach an asymptotic value at the highest ration levels tested (Fig. 4A). In seeking a statistical model with which to fit these data, we include our estimate of standard respiration which, in the absence of ingested food, represents the negative scope for growth to be associated with $5 \mathrm{~d}$ starvation (viz. $5.0 \pm 0.22 \mathrm{~J} \mathrm{~h}^{-1}$ ). The model chosen was:

$$
\mathrm{SFG}=a_{1}\left(1-\mathrm{e}^{-a_{2}\left(\mathrm{POM}-\mathrm{a}_{3}\right)}\right)
$$

where $a_{1}=$ maximum scope for growth; $a_{2}=$ rate at which this maximum is approached with increasing concentration of POM; and $a_{3}=$ concentration of POM at which SFG is zero. The statistical fit $\left(F_{(3,7)}=115 ; p<\right.$ $0.001 ; r^{2}=94 \%$; see legend to Fig. 4 a) suggests a maximum SFG of $11.5 \pm 1.0 \mathrm{~J} \mathrm{~h}^{-1}$, and a food concen-

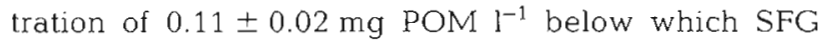
will be negative. In Fig. 4b SFG is plotted against the absorbed ration (AR; $F_{(1,8)}=546 ; p<0.001 ; r^{2}=99 \%$ ); the intercept on the AR axis signifies the rate of absorption necessary to maintain zero SFG (i.e. the maintenance ration) and calculates at $5.44 \pm 0.91 \mathrm{~J} \mathrm{~h}^{-1}$. The slope of this linear relation between SFG and AR is a

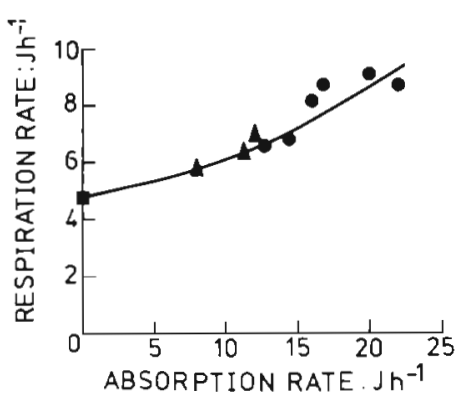

Fig. 3. Mytilus edulis. Respiration rates, Routine respiration rates $\left(\mathrm{R}_{;} \mathrm{Jh}^{-1}\right)$ are related to absorbed ration $\left(A R_{;} \mathrm{Jh}^{-1}\right)$, for mussels of $1 \mathrm{~g}$ dry flesh wt, by: $R=e^{(1.55 \pm 0.05+0.03 \pm 0.003 \mathrm{AR})} ; r^{2}=$ $90 \%$
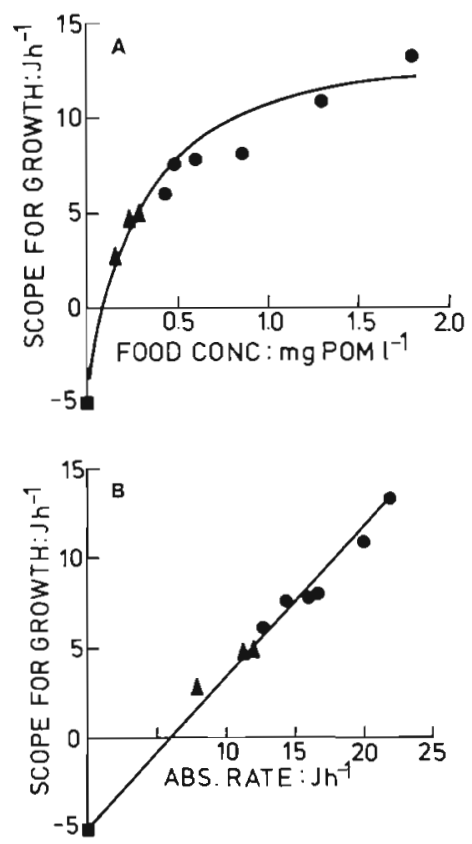

Fig. 4. Mytilus edulis. Growth response. (A) Scope for growth (SFG; $\mathrm{J} \mathrm{h}^{-1}$ ) as a function of the concentration of particulate organic matter (POM; $\left.\mathrm{mgl}^{-1}\right): \quad \mathrm{SFG}=11.5 \pm 1.0(1-$ $\mathrm{e}^{-2.8 \pm 0.5(\mathrm{POM}-0.11 \pm 0.02)} ; r^{2}=94 \%$. (B) Scope for growth $(\mathrm{SFG}$; $\left.\mathrm{Jh}^{-1}\right)$ as a function of the absorbed ration $\left(\mathrm{AR}_{;} \mathrm{Jh}^{-1}\right)$ : $\mathrm{SFG}=$ $0.78 \pm 0.03 \mathrm{AR}-4.31 \pm 0.49 ; r^{2}=99 \%$ 
measure of the maximum net growth efficiency (= $0.78 \pm 0.03)$.

\section{DISCUSSION}

These experiments aimed to simulate feeding conditions experienced by mussels in their natural habitat in order to investigate how Mytilus edulis responds to different levels of suspended particulate matter, when allowed time in the laboratory to acclimate to the dietary conditions. Such experiments are complementary to measures made 'in the field', with natural seston as available food (e.g. Bayne \& Widdows 1978, Widdows et al. 1979, Rodhouse et al. 1984) and to laboratory determinations based on varying the concentration of a single algal species (e.g. Winter 1973, Foster-Smith 1975, Schulte 1975). In Table 4 the conditions set-up for these experiments are compared with measurements made by Widdows et al. (1979) at the site from which the mussels were collected.

The experimental conditions (Table 1) were therefore representative of the lower end of the range in natural seston concentrations, and simulated well the ambient levels of POM. In the event, the measured rates of ingestion of organic material $\left(0.5\right.$ to $\left.2.0 \mathrm{mg} \mathrm{h}^{-1}\right)$ and of absorption of energy ( 8 to $26 \mathrm{~J} \mathrm{~h}^{-1}$ ) were very similar to those recorded in the field by Widdows et al. (1979; 0.6 to $2.3 \mathrm{mg}$ POM ingested $\mathrm{h}^{-1}$ ) and by Bayne \& Widdows $\left(1978 ; 7\right.$ to $38 \mathrm{~J}_{\text {absorbed }} \mathrm{h}^{-1}$ ), respectively.

Rates of ingestion increased with increased seston concentration, but at a decreasing rate, to reach a maximum at the highest diets tested; this is consistent with the observations of Winter (1978) and Widdows et al. (1979). Our data confirm the further suggestion (Winter 1978; but cf. Kiørboe et al. 1980) that the threshold seston concentration at which pseudofaeces are first produced coincides with maximum ingestion rates. We detected a marginal and intermittent production of pseudofaeces at $3.2 \mathrm{mg}$ seston $\mathrm{l}^{-1}$ (which was so slight as not to warrant quantification) and a significant production ( $22 \%$ of material filtered from suspension) at $7.4 \mathrm{mg} \mathrm{I}^{-1}$.

As ingestion rate increased, the residence time for particles within the gut declined. In an earlier study

Table 4. Comparison of field measurements (Widdows et al. 1979) with laboratory conditions (present study)

\begin{tabular}{|lcc|}
\hline & Widdows et al. & Present study \\
\hline Total seston $\left(\mathrm{mg} \mathrm{l}^{-1}\right)$ & $4.5-35$ & $0.8-7.4$ \\
Organic matter $\left(\mathrm{mg} \mathrm{l}^{-1}\right)$ & $1.1-2.0$ & $0.4-1.8$ \\
Organic fraction $(\%)$ & $5-30$ & $18-71$ \\
\hline
\end{tabular}

(Bayne et al. 1987) we observed, in mussels responding over $2 \mathrm{~d}$ to a change in diet, an increase in absorption efficiency with increased GPT. However, when these same mussels were maintained for $2 \mathrm{wk}$ on the experimental diets, absorption efficiencies increased with no change in gut passage time. In the present experiments, in which the mussels were acclimated for $2 \mathrm{wk}$, absorption efficiencies were similar between diets, in spite of differences in GPT. It is possible, given the plasticity that has been observed in the production of digestive enzymes by some bivalves (Seiderer et al. 1982, Seiderer \& Newell 1985), that Mytilus edulis may modify its rates of digestion by changes to the amounts and/or activities of digestive enzymes produced in different food environments. In this way it may balance the rate of ingestion against the production and activity of its digestive enzymes, thereby maximising absorption efficiency over a range of food quantities. This hypothesis is currently being tested.

Further, with due time for acclimation (within $2 \mathrm{wk}$ ), Mytilus edulis appears to adjust the volume of material held within the gut in proportion to the food's organic content, at a level that is relatively invariant with respect to the quantity of food available. The coupling between ingestion rate and gut passage time serves to maintain a constant volume of organic matter within the digestive system which, if linked with a production of digestive enzymes balanced against the rate of passage of food, may further help in optimising digestive efficiency.

Respiration rates increased with increased ration and, at the highest ration levels, reached values ( 8 to 9 $\mathrm{J} \mathrm{h}^{-1}$ ) similar to those recorded by Bayne \& Widdows $\left(1978 ; 8\right.$ to $\left.13 \mathrm{~J} \mathrm{~h}^{-1}\right)$ in their field study of mussels in the Lynher estuary.

The fitted relation (Fig. 3) between routine respiration rate and absorbed ration predicts a respiration rate of $4.71 \pm 1.05 \mathrm{~J}^{-1} \mathrm{~h}^{-1}$ at zero absorption; this is the maintenance metabolic rate. The maintenance ration (or maintenance requirement), defined as the rate of absorption at which scope for growth was zero (Fig. 4B) was $5.44 \pm 0.91 \mathrm{~J} \mathrm{~g}^{-1} \mathrm{~h}^{-1}$. The difference between these 2 values $\left(0.73 \mathrm{~J} \mathrm{~g}^{-1} \mathbf{h}^{-1}\right)$ is an estimate of the metabolic costs associated with the rates of feeding and digestion that are required to maintain the mussel at an energy equilibrium of zero growth. At the maintenance level, therefore, and for this particular diet of mixed algae and silt, $13 \%$ absorbed energy intake was required for feeding and digestion, and $87 \%$ for maintenance processes per se. Working with smaller mussels (10 mg dry flesh weight) feeding on a unialgal diet (Phaeodactylum), Widdows \& Hawkins (1988) record measurements to suggest that ca $11 \%$ of the absorbed ration was spent on feeding and digestion and $89 \%$ on maintenance, at maintenance ration. 


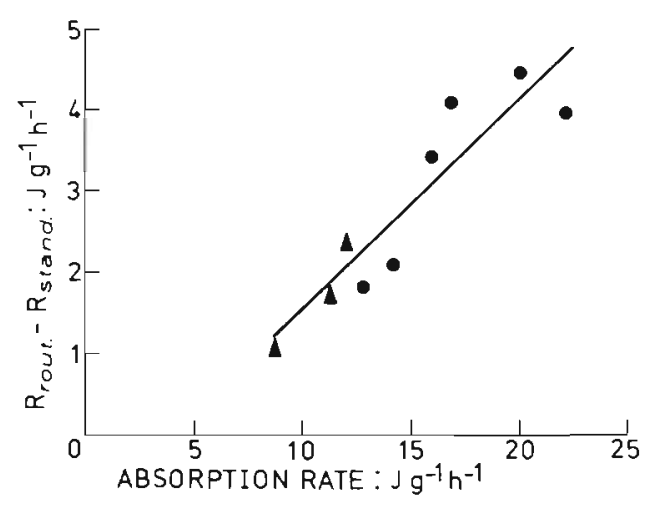

Fig. 5. Mytilus edulis. Increment between routine $\left(\mathrm{R}_{\text {rout }}\right)$ and standard $\left(R_{\text {stand }}\right)$ rats of respiration $\left(\mathrm{J} \mathrm{g}^{-1} \mathrm{~h}^{-1}\right)$ related to rate of absorption (= absorbed ration; $A R$ ) of energy from the diet (also as $\mathrm{J} \mathrm{g}^{-1} \mathrm{~h}^{-1}$ ). The line is fitted by the equation $R_{\text {rout }}-R_{\text {stand }}$ $=0.21 \pm 0.03 \mathrm{AR}-0.51 \pm 0.46 ; r^{2}=84 \%$

The energy available for growth increased with increased ration, but at a declining rate; below a particle concentration of $0.1 \mathrm{mg}$ POM l${ }^{-1}$ the scope for growth was negative as the metabolic costs of maintenance exceeded the gains due to absorption; scope for growth reached a maximum value of between 11 and $12 \mathrm{~J} \mathrm{~g}^{-1} \mathrm{~h}^{-1}$ dry wt at a concentration of ca $1.5 \mathrm{mg} \mathrm{POM} \mathrm{l}^{-1}$. These values are in keeping with results of Bayne \& Widdows (1978) for mussels measured at the collection site. One aim of this study was to estimate the metabolic costs associated with feeding and growth and to determine to what extent such costs might limit growth potential.

The maintenance metabolic rate was estimated to be $4.71 \mathrm{~J} \mathrm{~g}^{-1} \mathrm{~h}^{-1}$, and is assumed (see Widdows \& Hawkins 1988 ) to be constant across all rations. The increment between this value and the observed routine respiration rate is due to the metabolic costs of feeding, digestion and growth. This increment is plotted in Fig. 5 against the rate of absorption (= absorbed ration; AR). The equation describing this relation (see legend to Fig. 5) may be used to calculate the proportion of the absorbed ration utilised for feeding and growth (Fig. 6); this proportion increases from $16 \%$ at twice the maintenance ration to $22 \%$ at $4 \times$ maintenance. Widdows \& Hawkins (1988), using direct calorimetry to measure metabolic heat output, have estimated that the sum of feeding and growth costs in small individuals of Mytilus edulis amount to between 18 and $28 \%$ of the absorbed ration. These values represent a significant cost, to the individual of the processes of feeding and growth; at the highest ration levels tested here, at which the scope for growth was maximal (Fig. 4A), ca $25 \%$ of the absorbed energy was spent on each of maintenance and growth.

Constraints on feeding behaviour, which limit the rate of absorption of energy from the ingested diet, represent another significant limiting factor to growth.

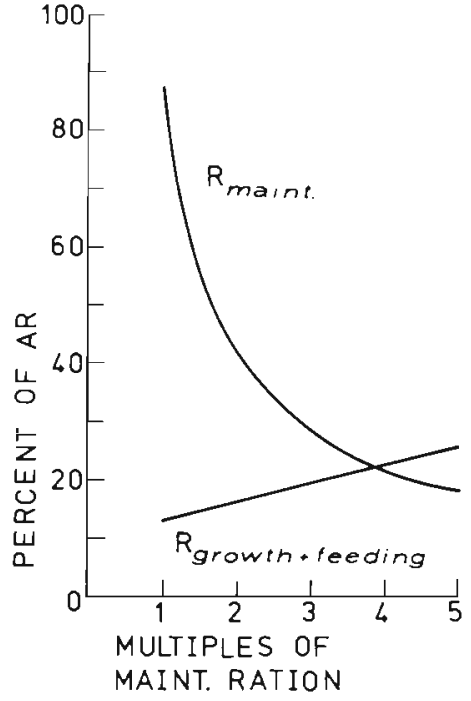

Fig. 6. Mytilus edulis. Proportion of absorbed ration (AR) utilised in maintenance $\left(\mathrm{R}_{\text {maint }}\right)$ and in growth and feeding $\left(R_{\text {growth }}+\right.$ reeding $)$, at different multiples of the maintenance ration (see text)

At low ration levels, extended gut passage times support high absorption efficiencies and the mussels are able to respond rapidly to increase the energy available for growth with increased rates of ingestion. At higher ration levels, a high absorption efficiency is maintained in spite of much reduced residence time of food in the gut; the scope for growth is maximised over a range of food concentrations that encompasses the maximum ingestion rate at and beyond the threshold for the production of pseudofaeces. At these higher food concentrations, however, the capacity for energy absorption is fully occupied (maximum ingestion rate, gut fullness and absorption efficiency), and only a significant increase in food quality (to greater than $0.45 \mathrm{mg}$ POM per $\mathrm{mm}^{3}$ of total particulate material) would offer further opportunity for an increase in growth.

These mussels seem well able, then, to maintain rates of growth over a wide range of both quality (Bayne et al. 1987) and quantity of ration, by balancing rates of ingestion against elements of digestive physiology to effect constant absorption efficiencies (see also Navarro \& Winter 1982). The metabolic costs of feeding behaviour (filtration, gut passage and digestion) appear to be low relative to overall metabolic rate (Widdows \& Hawkins 1988), so that adjustments in feeding behaviour are not heavily 'taxed' in metabolic terms; similar relationships appear to apply for planktonic copepods (Kiorboe et al. 1985). At the higher food concentrations tested in these experiments the combined costs of feeding and growth were approximately one-quarter the absorbed ration. At even higher concentrations of suspended particulate matter, the 
demands of sorting material for ingestion for the rejection as pseudofaeces may increase, imposing a further tax on growth potential. Nevertheless, the morphological constraints inherent in feeding and digestion, rather than the associated metabolic costs of these processes and growth, seem to impose the critical limits to growth at environmentally realistic levels of food

Acknowledgements. We are grateful to Mandy Day and Colin Worrall for their help with these experiments. This work is part of the Adaptive Processes project of the Plymouth Marine Laboratory in collaboration with the Universidad del Pais Vasco, Bilbao. EN is grateful to Action Integrada for support.

\section{LITERATURE CITED}

Bayne, B. L., Hawkins, A. J. S., Navarro, E. (1987). Feeding and digestion by the mussel Mytilus edulis L. (Bivalvia: Mollusca) in mixtures of silt and algal cells at low concentrations. J. exp. mar. Biol. Ecol. 111: 1-22

Bayne, B. L., Newell, R. C. (1983). Physiological energetics of marine molluscs. In: Saleuddin, A. S. M., Wilbur, K. M. (eds.) The Mollusca, Vol.4, Physiology, Part1. Academic Press, New York, p. 407-515

Bayne, B. L., Widdows, J. (1978). The physiological ecology of two populations of Mytilus edulis L. Oecologia (Berl.) 37 : $137-162$

Buss, L. W. Jackson, J. B. C. (1981). Planktonic food availability and suspension-feeder abundance: evidence of in situ depletion. J. exp. mar. Biol. Ecol. 49: 157-161

Cloem, J. E. (1982). Does benthos control phytoplankton biomass in south San Francisco Bay? Mar Ecol. Prog. Ser. 9: 191-202

Conover, R. J. (1966). Assimilation of organic matter by zooplankton. Limnol. Oceanogr. 11: 338-345

Doering, P. H., Oviatt, C. A. (1986). Application of filtration rate models to field populations of bivalves: an assessment using experimental mesocosms. Mar. Ecol. Prog. Ser 31. 265-275

Foster-Smith, R. L. (1975). The effect of concentration of suspension on the filtration rates and pseudofaecal production for Mytilus edulis L., Cerastoderma edule (L.) and Venerupis pullastra (Montagu). J. exp. mar. Biol. Ecol. 17. 1-22

Gnaiger, E. (1983). Calculation of energetic and biochemical equivalents of respiratory oxygen consumption. In: Gnaiger, E., Forstner, H. (eds.) Polarographic oxygen sensors. Springer-Verlag, Berlin. p. 337-345

Griffiths, R. J. (1980). Natural food availability and assimilation in the bivalve Choromytilus meridionalis. Mar. Ecol. Prog. Ser. 3: 151-156

Incze, L. A., Lutz, R. A., Watling, L. (1980). Relationships between effects of environmental temperature and seston on growth and mortality of Mytilus edulis in a temperate Northern estuary. Mar. Biol. 57. 147-156

Kautsky, N., Evans, S. (1987). Role of biodeposition by Mytilus edulis in the circulation of matter and nutrients in a Baltic coastal ecosystem. Mar. Ecol. Prog. Ser 38: 201-212

Kiørboe, T., Møhlenberg, F., Nøhr, O. (1980). Feeding, particle selection and carbon absorption in Mytilus edulis in different mixtures of algae and resuspended bottom material. Ophelia 19: 193-205

This article was submitted to the editor
Kiorboe, T., Møhlenberg, F., Nøhr, D. (1981). Effect of suspended bottom material on growth and energetics in Mytilus edulis. Mar. Biol. 61: 283-288

Kiorboe, T. Mohlenberg, F., Hamburger, K. (1985). Bioenergetics of the planktonic copepod Arartia tonsa: relation between feeding, egg production and respiration, and composition of specific dynamic action. Mar. Ecol. Prog. Ser 26: 85-97

Navarro, J. M., Winter, J. E. (1982). Ingestion rate, assimilation efficiency and energy balance in Mytilus chilensis in relation to body size and different algal concentrations. Mar. Biol. 67: 255-266

Officer, C. B., Smayda, T J., Mann, R. (1982). Benthic filter feeding: a natural eutrophication control? Mar. Ecol. Prog. Ser. 9: 203-210

Rodhouse, P. G., Roden, C. M., Hensey, M. P., McMahon, T., Ottway, B., Ryan, T H. (1984). Food resource, gametogenesis and growth of the mussel Mytilus edulis on the shore and in suspended culture: Killary Harbour, Ireland. J. mar. biol. Ass. U. K. $64: 513-529$

Schulte, E. H. (1975). Influence of algal concentration and temperature on the filtration of Mytilus edulis. Mar. Biol. 30: 331-341

Seiderer, L. J., Newell, R. C. (1985). Relative significance of phytoplankton, bacteria and plant detritus as carbon and nitrogen sources for the kelp bed filter-feeder Choromytilus meridionalis. Mar Ecol. Prog. Ser. 22: 127-129

Seiderer, L. J., Newell, R. C., Cook, P. A. (1982). Quantitative significance of style enzymes from two marine mussels (Choromytilus meridionalis Krauss and Perna perna Linnaeus) in relation to diet. Mar. Biol. Lett. 3: 257-271

Smaal, A. C., Verhagen, J. H. G., Coosen, J., Haas, H. A (1986). Interaction between seston quantity and quality and benthic suspension feeders in the Oosterschelde, the Netherlands. Ophelia 26: 385-399

Taghon, G. L. (1981). Beyond selection: optimal ingestion rate as a function of food value. Am. Nat. 118: 202-214

Taghon, G. L., Jumars, P. A. (1984). Variable ingestion rate and its role in optimal foraging behaviour of marine deposit feeders. Ecology 65: 549-558

Tenore, K. R., Dunstan, W. M. (1973). Comparison of feeding and biodeposition of three bivalves at different food levels. Mar Biol. 21 190-195

Thompson, R. J., Bayne, B. L. (1972). Active metabolism associated with feeding in the mussel Mytilus edulis $\mathrm{L} . \mathrm{J}$ exp. mar. Biol. Ecol. 8: 191-212

Widdows, J., Fieth, P., Worrall, C. M. (1979). Relationships between seston, available food and feeding activity in the common mussel Mytilus edulis. Mar B1ol. 50: 195-207

Widdows, J., Hawkins, A. J. S. (1989). Partitioning of rate of heat dissipation by Mytilus edulis into maintenance, feeding and growth components. Physiol. Zool. (in press)

Wilson, J. H. (1987). Environmental parameters controlling growth of Ostrea edulis L. and Pecten maximus L. in suspended culture. Aquaculture 64: 119-131

Winter, J. E. (1973). The filtration rate of Mytllus edulis and its dependence on algal concentration, measured by a continuous automatic recording apparatus. Mar Biol. 22 $317-328$

Winter, J. E. (1978). A review on the knowledge of suspension-feeding in lamellibranchiate bivalves, with special reference to artificial aquaculture systems. Aquaculture 13: $1-33$

Manuscript first received: January 18, 1989

Revised version accepted: April 14, 1989 